\title{
The Dissemination of Preservation Information in the Republic of South Africa Kate Murray
}

The Republic of South Africa has a modest but established preservation community within its sizable library and archive sectors. Because limited professional education and training opportunities are available within the country, many information professionals heavily rely on other means outside the traditional classroom environment to get information about preservation developments and activities. This article explores the distribution methods and associated challenges surrounding the dissemination of preservation information in South Africa.

\section{The Republic of South Africa as a Developing Country}

The Republic of South Africa is a country of great extremes. It generally is considered the most industrialized country in sub-Saharan Africa, if not all of Africa, with an established infrastructure, abundant natural resources, and a stable government. At the same time, however, it is a country with significant work still to be done to improve its economy and the lives of its citizens. The global community categorizes South Africa as a developing country, but this term also is used to describe much poorer and politically unstable regions, such as South Africa's neighbor Zimbabwe. It is important to understand the intricacies of the term developing country or developing nation and how it applies specifically to South Africa. Dosa and Katzer define the term as "an economically developing entity ... used with the understanding that the rich diversity of these countries cannot be subjected to generalizations" (1991, 86).

Because of its political and cultural history, the world has long taken an interest in South African affairs. Many developed countries have invested a good deal of time, money, and effort toward exchanging knowledge and forging working relationships with South African professionals. This is not the case with all developing countries, even in those with more pressing needs for organizational assistance, education, training, and funds. The reality of the South African situation is unique among developing nations, and it is difficult to make general statements about other developing nations based on the South African model. Although preservation is not well established within the library and archives professional communities or training programs, there is a dedicated core group actively promoting the preservation agenda within the country. South Africa, unlike most other developing nations, has a skeletal network to disseminate this information in and around the country. In short, because

South Africa is relatively well connected to the global community, it cannot be com) is a recent Master's Graduate of University of Cape Town Department of Information and Library Studies, Cape Town, South Africa, and now lives in Atlanta, Georgia. 
considered representative of how things work in other developing nations.

\section{Disseminating Preservation Information through Professional Organizations}

Professional organizations, both international and local, play a pivotal role in the dissemination of preservation information to professional information workers within South Africa's library and archive communities. Some are proactive in taking a dynamic lead; others are less so, by design or default. This article will discuss the activities of some of the major relevant organizations. Interorganizational cooperation is both necessary and common in large-scale preservation projects and, as a result, organizational participation often overlaps. It is not the purpose of this article to give an exhaustive recounting of each organization's history, but rather to give a general overview of the organization's relative success or failure in disseminating preservation information in South Africa.

\section{International Professional Organizations}

\section{IFLA: International Federation of Library Associations} and Institutions

The International Federation of Library Associations and Institutions (IFLA), a large, multinational lobbying body, has a noteworthy influence on the dissemination of preservation information in South Africa by publishing the quarterly IFLA Journal and, more intermittently, the International Preservation News (IPN), both of which report on global preservation activities. IFLA also maintains the increasingly valuable IFLANET Web site (www.ifla.org) and organizes training workshops and conferences. However, members of IFLA primarily are associations and institutions, not individuals, so the onus is on the organizational members to distribute these resources to their individual members.

Two IFLA components have vested interests in South African preservation: the Preservation and Conservation (PAC) Core Program and the Africa Regional Section. Launched in 1986, the primary goal of PAC is "to raise awareness: to make information and heritage professionals, governments, and the public conscious of the fundamental position occupied by preservation in the management of an institution" (IFLA 2001). PAC's Principles for the Care and Handling of Library Material, edited by Adcock, is a wellrespected contribution to the preservation field and readily available thanks to its recent posting on IFLANET (Adcock 1998). The Africa Regional Section also has a strong interest in preservation, listing "the promotion of conservation and preservation of library and archival material in Africa" as one of its goals in the 2002-2003 Plan of Action (IFLA 2002a). The 1993 Report of the IFLA Mission to South Africa identified the relative isolation of South African library and information science professionals from specifically their neighboring African colleagues (IFLA 1993). Partially to encourage more intracontinental discourse, the Africa Regional Section has sponsored the Bart Nwafor Staff Development Program since 1997 to further networking within Africa in several areas, one of which is preservation training.

One of the benchmark moments in the modern history of preservation in continental Africa was the 1993 PanAfrican Conference on the Preservation of Library and Archive Materials held in Nairobi, Kenya. This cornerstone event was organized by PAC, another IFLA Core Program by the name of the Advancement of Librarianship Program (ALP), the Africa Regional Section, and the International Council on Archives (ICA), with funding from a number of sources including United Nations Educational, Scientific, and Cultural Organization (UNESCO) and the World Bank (Bergdahl 1993, 464). The resulting conference resolutions had a wide range, from acknowledging the "general lack of awareness of preservation and conservation of library and archival materials ... [and advocating that these] disciplines undertake awareness-raising activities at the institutional and national levels," to advocating the "establishment in each country of a committee to develop a national preservation policy," to addressing the lack of standards for Africa, and to improving preservation education and training (Bergdahl 1993, 464). Many of these resolutions have not been implemented adequately, but the conference did have one successful continuing result-the eventual creation of the Joint IFLA/ICA Committee for Preservation in Africa (JICPA).

\section{UNESCO: United Nations Educational, Scientific, and Cultural Organization}

Founded in 1945, UNESCO has a long, but uneven, history in preservation education and distributing preservation information. On the positive side, UNESCO has "demonstrated a commitment to developing a libraries-and-archives work force because of shortages of such personnel in many parts of the world" (Cloonan 1994, 31). Cloonan goes on to say that UNESCO has funded numerous "fellowships, scholarships, travel grants, international courses and seminars, teacher exchanges, and the establishment of new library schools" in the developing areas of the world $(1994,31)$. Nonetheless, both Cloonan (1994) and Lancaster (1991) discuss the problems with these UNESCO-sponsored educational activities, including the lack of course follow-up and the inconsistent background knowledge of participants. Naturally, these issues are not restricted to UNESCO initiatives alone. 
Speaking specifically of hands-on conservation training workshops organized by JICPA, Varlamoff and Kremp question the benefit of short workshops saying that "as there is no real follow up, it is difficult to check whether all the trainees become trainers when they go back to their country, and whether because of strenuous economical situations, they can put into practice what they have been taught" (2000, 223).

One of the major contributions of UNESCO to the dissemination of preservation information is the Memory of the World program, founded in 1992 in conjunction with IFLA to "protect and promote the world's documentary heritage" (UNESCO General Information Program 1994, 350). The Memory of the World Register "lists documentary heritage which has been identified by the International Advisory Committee in its meetings . . . and endorsed by the Director-General of UNESCO as corresponding to the selection criteria for world significance" (UNESCO 2001). The program is based firmly in preservation in that it is "designed to embody a new approach to protecting endangered documentary heritage, democratizing access to it and ensuring its wider dissemination" (UNESCO General Information Program 1994, 351).

UNESCO's second major contribution is in the field of publications. The UNESCO Records and Archives Management Program (RAMP) studies cover a wide range of topics including disaster planning, mold treatment in tropical climates, general preservation and conservation for libraries and archives, and environmental pollution and its effects on library materials, as well as guidelines for training preservation specialists (Buchanan 1988; Wood Lee 1988; Clements 1987; Pascoe 1988; Kathpalia 1984). Some of the RAMP studies are available online via the UNESCO Archives Portal (www.unesco.org/webworld/portal_archives/ramp_studies_ list.html) with plans in place to add more titles in the future. Online availability will help make the RAMP studies more accessible because as Cloonan mentions, UNESCO "has not always been attentive to responding to written requests [for hard copies] and sometimes the wrong [publications] are mailed out" $(1994,32)$.

\section{ICA: International Council on Archives}

Through its affiliation and cooperation with UNESCO, IFLA, and JICPA, the International Council on Archives (ICA) strives to fulfill its mission of "facilitating the training of new archivists and conservators and the continuing education of working archivists and conservators" and "developing relations between archivists of all countries and between all institutions which are concerned with the administration or preservation of records and archives or the professional training of archivists" (ICA 2002). Like IFLA, ICA has a number of regional sections or branches with ESARBICA (Eastern and Southern Africa Regional Branch of the International Council on Archives) being the relevant section for South African professionals. ESARBICA's constitution was adopted in Nairobi, Kenya, in 1969. The organization publishes the ESARBICA Journal and ESARBICA Newsletter. In addition, ICA runs the Committee on Preservation in Tropical Climates (ICA/CPTC), a field of study important for sometimes steamy South Africa.

Another preservation education-related project in which ICA is involved is the International Committee of the Blue Shield (ICBS or Blue Shield). Formed in 1996 by the ICA, ICOM (International Council of Museums), the International Council for Monuments and Sites (ICOMOS), and IFLA, the purpose of ICBS is "to collect and disseminate information and to coordinate action in emergency situations. Its mission is to protect and safeguard cultural heritage" (ICA 2002). It describes itself as "the cultural equivalent of the Red Cross" (IFLA 2001). ICA and IFLA publish ICBS project updates in their publications and on their respective Web sites.

\section{JICPA: Joint IFLA/ICA Committee for Preservation in Africa}

The 1996 creation of the Joint IFLA/ICA Committee for Preservation in Africa (JICPA) is a direct result of the resolutions stemming from the 1993 Pan-African Conference in Nairobi. The goal of JICPA is "to help raise awareness among African professionals of the purpose and importance of preservation. Its aim is also to make professionals aware of all the problems of preservation and to prepare them to deal with these problems" (JICPA 2001). Currently, JICPA is under the organizational umbrellas of both IFLA and ICA, but may become a project of the IFLA Africa Regional Section alone (IFLA 2002b, 3)

In South Africa, JICPA has recently integrated with SAPCON (South African Preservation and Paper Conservation Group). JICPA is still active throughout Africa, but not as a separate entity within South Africa. There are current, influential South African-based members within JICPA, but the JICPA group no longer organizes or sponsors initiatives for the South African preservation community. SAPCON has taken over this role.

Although no longer a discrete unit within South Africa, JICPA has made several important contributions to African preservation awareness, including completing the Survey of Preservation Resources in Africa 1999 (Coates 2001). Training is an important aspect of JICPA's constitution, and it has organized and conducted several preservation workshops including the Safeguarding African Documentary Heritage workshop in Cape Town, South Africa, in early 2001. This workshop was cosponsored by UNESCO's 
Memory of the World program and the National Library of South Africa (NLSA) in cooperation with IFLA PAC.

\section{Conclusions about the Role of International Professional Organizations}

Clearly, some international organizations are making a proactive effort to distribute preservation information to their members and succeeding to varying degrees. The efforts of international professional organizations cannot be counted as sufficient, however. African professionals, including Mazikana $(1995,27)$ and Coates $(2001,7)$, stress that international initiatives must emphasize capacity building and self-reliance to be successful in the long term. In addition, local grassroots-sponsored programs must balance international efforts in order to have an effective lasting impact in the region. South African professional organizations must pick up where the international organizations leave off.

\section{South African Professional Organizations}

\section{SAPCON: South African Preservation and Paper Conservation Group}

SAPCON, the South African Preservation and Paper Conservation Group, is the local professional organization that deals specifically with the preservation and conservation of cultural heritage collections in South Africa. This includes institutional library and archive collections, as well as museums and historical societies.

SAPCON's focus has changed recently. Previously known as the South African Paper Conservation Group (under the same acronym SAPCON), the new name emphasizes the many aspects of preservation aside from hands-on paper conservation. Simultaneous with the name change, SAPCON recently amalgamated with the South African JICPA members to reduce the overlap between the two similarly focused groups. The recent name change also reflects a desire to attract a wider membership base with more diverse areas of specialties and interests. While SAPCON continues to focus on paper-based materials, the scope of responsibility has broadened to include "works of art, artifacts, library and archival materials and photographs on, or composed of, paper and related materials" (SAPCON 2001). The inclusion of the word "preservation" in the group's name implies that the group will consider these materials in new formats, such as exploring digitization projects. The major aim of the revamped SAPCON is "to advance the education of the public in the conservation of all cultural heritage artifacts, paper and related materials for the purpose of maintaining our South African heritage" (SAPCON 2001).

As the main preservation touch point in South Africa, SAPCON is an important influence on preservation educa- tion in the region. As a group, it stresses professional networking, investigation, and materials research as well as outreach projects (SAPCON 2001). Established in 1985, the group is organized into geographic chapters or regional groups under a national executive committee. Each regional group decides its own events, with the scheduled presentations often organized or led by the members of that section. Occasionally, SAPCON chapters organize events in conjunction with other chapters or other organizations. For example, SAPCON West organized the May 2001 DeMystifying Digital Imaging: Building a South African Bitmap workshop in Cape Town, which was partially funded by the Council on Library and Information Resources (CLIR) and immediately followed NEDCC's (Northeast Document Conservation Center) To Film or To Scan fourday workshop (which was also organized by SAPCON West members). To promote local expertise, the SAPCON/CLIR digital imaging workshop instructors were working South African professionals to balance the visiting Americans of NEDCC.

As a whole, SAPCON is an active, progressive organization, and the possibilities for SAPCON in furthering preservation education throughout the country are endless. Nevertheless, the group struggles at times with achieving its potential in part because SAPCON has a difficult time effectively getting information to its members. No regular mailings or newsletters keep members in touch with the group and each other. These same communication problems hinder the recruitment of new members, especially from the paraprofessional and student ranks. How can interested parties join if they do not know whom to contact, the benefits of membership, or the types of projects in which the organization is involved? More directly, how can they become members if they do not know the organization even exists? Efforts are underway to improve intra-organizational communication, including developing a national Web site and, very recently, the establishment of the SAPCON electronic mailing list. This may not alleviate the communication problem for all existing and potential members since Internet access is limited for some information professionals, but it is a positive step. As SAPCON moves away from the often self-employed, hands-on, close knit conservation community toward the larger institution-based preservation community, the group's infrastructure slowly is evolving to meet the demands of the new direction.

\section{SASA: South African Society of Archivists}

The South African Society of Archivists (SASA) was founded in 1960 and defines the "moral duty to preserve information about the past and present for the future" as the first responsibility of an archivist (SASA 2001). Like SAPCON, SASA 
has regional chapters or branches, but its communication network is more established than SAPCON's with a Web site, a journal (S. A. Archives Journal), and a newsletter (SASA Newsletter).

SASA's mission, however, does not focus on the training of individuals, but rather the professional development and conduct of the South African archives field as a whole. SASA, nevertheless, has made contributions to disseminating preservation information, specifically in the area of establishing professional standards for the archives profession. One example is the Standards Generating Body for Archives and Record Management (SGB-ARM) of the South African Qualifications Authority (SAQA), which lists preservation as a primary function of an archivist (SAQA SGB-ARM 2001). Aside from this, the organization has made other efforts to promote and further preservation in South Africa. A case in point is the partially SASA-sponsored Preserving Library and Archival Materials in Africa: Opportunities and Challenges conference held in Durban, South Africa, in December 2002.

\section{LIASA: Library and Information Association of South Africa}

The Library and Information Association of South Africa (LIASA) was launched in 1997, taking over from the South African Institute for Librarianship and Information Science (SAILIS) and the African Library Association of South Africa (ALASA) (LIASA 2002). LIASA is the main professional organization for South African library and information workers. Organized into regional or provincial branches, members have access to a national Web site and receive regular national and regional news via mail and email. In addition, LIASA recently has assumed publication responsibility for the South African Journal of Libraries and Information Science (SAJLIS), previously known as the South African Journal of Library and Information Science (same acronym, SAJLIS).

LIASA's mission focuses on advocacy and is policy-oriented as opposed to providing training for its members. There is no organized preservation group or committee in this organization, although members are free to form a new interest group at any time. Coates notes that LIASA's predecessor, SAILIS, "started a division for conservation librarians, but it was so bogged down with rules and regulations, it met virtually no support and collapsed at once" (1995, 39). The fact that no such group currently exists in LIASA may be a reflection of the general apathy toward preservation within the library and archive sector in South Africa. LIASA does hold occasional disaster preparedness workshops, but currently preservation is not a key focus for this organization.

\section{SAMA: South African Museums Association}

While not an organization that focuses strictly on the activities of libraries or archives, the South African Museums Association (SAMA) nonetheless has an impact on disseminating preservation information within these sectors through its various training opportunities and workshops. Founded in 1979, SAMA's mission focuses on the "the management of the country's diverse natural and cultural heritage" in the field of museology which, aside from museums proper, can include "other educational and kindred institutions" such as "archives, herbaria, conservation institutes, and collections and exhibitions permanently maintained by libraries, universities, colleges, and schools" (SAMA 2001). While SAMA does not specifically list preservation as one of its main objectives, it does focus closely on the issue of professional ethics and conduct, which can include preservation ethics for all types of heritage institutions.

\section{Conclusions about the Role of South African Professional Organizations}

Every South African professional organization does not have an obligation to focus only on preservation; different organizations have different raisons d'être. Yet every professional organization does have the responsibility to ensure its members are kept well informed and up to date in their respective fields. Perhaps organizations like LIASA and SASA limit their role in preservation awareness intentionally, while SAMA chooses to take a more proactive approach, although there is no data to support or deny this claim. SAPCON is the obvious local choice for disseminating preservation information throughout the various cultural heritage sectors, but, at this point, SAPCON is struggling to find its footing in its new expanded environment. Its renewed efforts to improve communication with its members also will improve communication with other professional organizations. In the meantime, the other organizations have a responsibility to their members to continue, or in some cases to begin, the preservation education discussion, individually or collectively.

\section{Other Methods of Information Dissemination}

Preservation information is distributed to and within the South African information professional community in other ways aside from through professional organizations. Some are more accessible than others. Imported professional journals and newsletters like Restaurator and The Abbey Newsletter are relevant, but very expensive in constantly fluctuating foreign currency. Few institutions or individuals in South Africa can afford to subscribe consistently. Others, 
like IFLA PAC's IPN, are more widely received, but more sporadically published. The journals and newsletters of local professional organizations and institutions are much easier to obtain, but at the time of this writing no local journal or column is dedicated to preservation issues.

Electronic mailing lists are another option that has proved successful in many library and archive specialties. Aside from the appeal of being free of charge and suffering virtually no publishing delays, electronic mailing lists need not be geographically restricted. One of the most successful examples in the field is the Conservation Distribution List or Cons DistList (http://palimpsest.stanford.edu), moderated by Walter Henry at Stanford University, which has subscribers from more than twenty countries across a variety of disciplines. Another is the Encoded Archival Description (EAD) Electronic List (www.loc.gov/ead/eadlist.html) run from the University of Virginia, which discusses metadata encryption for (mostly) archival digital imaging projects. Yet another is the Association for Library Collections and Technical Service's Preservation Administrators Discussion Group (PADG) list; information about this discussion list is available through the ALCTS Web site (www.ala.org/alcts). But, as a 2002 survey of South African preservation professionals reports, very few South African professionals subscribe to these lists, despite widespread Internet access of varying degrees (Murray 2002, 78). Personal communication, however, reveals that many are unaware of some of the more recognizable options like Cons DistList or at least unaware of how to subscribe. The establishment of SAPCON's new electronic discussion list is encouraging, but time will tell how successful the list will be.

\section{Problems with the Dissemination of Preservation Information outside of the United States}

The dissemination of preservation information across diverse geographic regions and population groups presents problems regardless of the distribution method.

\section{Limited Networking Opportunities}

Other, less formal means, aside from the traditional classroom setting, journals, and professional organizations, distribute preservation information. The most current information often is passed along informally among peers, through what is known as the invisible college or "the elite group of people who work in a particular field and who communicate with each other in an informal way" (Smith $1992,247)$. In short, the invisible college is a well-connected group of people who know who is doing what, where, when, why, and who is paying for it. The invisible college is an informal network of like-minded colleagues, who communicate with each other in person at seminars and conferences, on the phone, via fax and e-mail. Cloonan notes that the invisible college connects via specifically oral channels (1994, 62). This definition may be too narrow in today's online environment in which the computer keyboard is the telecommunication method of choice. Aside from this person-to-person communication, Smith notes that gray literature, defined as material ordinarily not available in library collections, like "conference pre-prints, reports of completed studies, reports, and recommendations of committees and photocopies of speeches given at conferences," is an integral aspect of the invisible college $(1992,241)$. The important point is that information is passed along informal communication channels. Smith asserts that the informal channels of the invisible college are more effective than professional literature $(1992,241)$.

But how does one participate in the invisible college? One does this by networking or "what the Americans call schmoozing" as one library fund-raising expert recently described it at a Cape Town grant-writing seminar. Networking or schmoozing can be very difficult, indeed, when one does not have a personal professional network or access to an established one.

\section{North to South Networking}

Because the invisible college is most entrenched in the United States, the same aspects that make it a successful information exchange tool also act as barriers for would-be recruits, especially international ones.

Because the invisible college in the United States preservation community is so saturated with news of itself, there is little motivation and less time for developing international links.... The invisible college in the international preservation community is considerably much less developed and consequently much less effective. This is not because the international preservation system is flawed, but rather because it is new. In many areas, the essential critical mass of preservation colleagues hasn't yet developed within national boarders, let alone a geographic region (Smith 1992, 247).

In other words, the frenetic pace of the preservation profession in the United States leaves the professional community little motivation to become involved with "outsiders" who may be geographically, culturally, or institutionally different or distant. Therefore international colleagues may encounter difficulty networking with their northern hemisphere counterparts on an equal footing. 
One example of north to south (developed nation to developing nation) networking in the preservation context is the role of international organizations, which are almost always based in the more industrialized countries and export their products and expertise to the less developed countries. North to south networking is only partially effective because of the inherent hierarchy in this relationship. The more successful projects have a balanced approach of both north to south and south to south exchange, such as the SAPCON/CLIR workshop piggybacking on the NEDCC workshop discussed earlier.

\section{South to South Networking}

While South African professionals may have difficulty developing reciprocal relationships with their American or European counterparts, this does not mean that a local scaled-down version of the invisible college is not in place within South Africa and even with its neighbors. This is known as south to south, or developing nation to developing nation, networking.

South Africa is a country of have and have nots, just like the United States, although the balance of inequity is more pronounced in South Africa. Large well-funded research institutions traditionally have funds to send staff for training and conferences at which they can build their professional networks. Those who work at these types of institutions have greater access to the Internet and more support from the higher levels of institutional administration to utilize these resources successfully. Those who work in smaller institutions, especially public or rural libraries, with limited resources often do not have the same opportunities as their counterparts in larger institutions. In their paper on training volunteer librarians for work in South African rural libraries, Hart et al. (2001) discuss the challenges and limitations of working with the have-not libraries. They highlight the lack of available resources and the need to reconsider traditional preservation options, saying "it was difficult to embrace options normally frowned upon by conservators, such as pressure-sensitive tapes and techniques that we [northern hemisphere preservation professionals] think of as 'quick fixes"' (Hart et al. 2001, 11). What may be difficult for someone coming from the United States to consider might not be difficult at all for a South African peer to accept as the norm. A set of South African preservation professionals developing guidelines for foreign volunteers might have anticipated supply issues, the lack of disaster plans, as well as the need to develop handouts and training materials in languages other than English. These cultural differences reiterate the need for local peer-topeer and south-to-south interaction.

A survey conducted in early 2002 showed that most preservation professionals claim to have a professional net- work of colleagues within South Africa, although the scope and framework of this network is not clear since limited occasions for information exchange exist outside conferences and workshops (Murray 2002). One promising new addition is the recently established SAPCON electronic mailing list that specifically focuses on preservation and conservation issues. Others include the DISA (Digital Imaging Project of South Africa) electronic mailing list for digitization projects and occasional announcements on wider scope electronic mailing lists like LIASA’s LIASAOnline.

\section{Lack of Standard Vocabulary}

Another ongoing challenge for international preservation communication is the lack of a globally standard professional vocabulary. Regional and language differences make communicating effectively across international borders difficult. Smith discusses some of the rather amusing confusion that can result from a nonstandard vocabulary in such a cosmopolitan field.

Variables (personality, education, social background, and national origin) play an even larger role in the international community where we also have to communicate across the barrier of language differences. For example, in English, the conservator is a person who performs physical, hands-on treatment of damaged library materials; whereas in French, the conservator is a person who oversees the development and care of a collection, or in American English, the curator. To the British, this person is the keeper. To Americans, a keeper is usually a person who looks after animals, as in "zoo keeper" (Smith 1992, 240).

This is but one humorous example of a very serious issue, the lack of an internationally standard vocabulary.

The differences are not just semantic. The problem points to the fact that, to some extent, the field has not clearly defined its benchmark terms and made them widely understood. Smith asks "what do we mean when we say 'archival,' 'permanent,' or 'acid-free'?" (1992, 240). These words are not interchangeable, but they often are misused incorrectly as synonyms. This misuse frequently leads to confusion. For example, one local South African library binder described his binder's board as "archival but not acid-free." How can something be archival if it contains the very substance known to hasten deterioration, acidic lignin? The confusion would be cleared up if a standard definition and clear understanding of the concept of archival existed.

Significant inroads into standardization have been made in recent years. Some of the notable examples include IFLA's Principles for the Care and Handling of 
Library Material (Adcock 1998), and Roberts and Etherington's Bookbinding and the Conservation of Books: A Dictionary of Descriptive Terminology (1982), both of which are available in paper format and electronic format online.

\section{Language Issues}

Most attempts at standardization, such as dictionaries and glossaries, are only available in the English language. Translation of professional preservation literature into other languages is a slow-moving process; and even when material is translated, it is usually only into Spanish, French, or occasionally Russian.

South Africa has eleven official languages. Aside from the very occasional home-produced item in Afrikaans, no preservation literature is available in the nine other languages. Most current South African preservation professionals are fluent (or nearly fluent) in English, although it is often a second language to Afrikaans, and they have access to the professional literature. Many information professionals outside the preservation field, however, speak English as a third, fourth, or later language and their fluency may not be as great. The current situation may be tolerable-but only just-from the South African perspective, although this language imbalance may inhibit new recruits into the field from outside the English- and Afrikaans-speaking populations.

Other countries, especially other developing countries where English fluency is not as prevalent as it is in South Africa, suffer serious gaps in knowledge due to this inequity of translation. A few professional organizations like IFLA and UNESCO are sensitive to this problem and make an effort to translate documents and make them as readily available as the English versions. The American Institute for Conservation of Historic and Artistic Works (AIC) has linked with the Association for the Conservation of the Cultural Patrimony of the Americas (APOYO) group to translate conservation documents into Spanish. There is still a long way to go. It is doubtful any professional preservation literature will ever be translated into Xhosa or Venda or Sotho or the like, unless it is a South African or perhaps Southern African Development Community (SADC) initiative.

\section{Future Directions}

Because preservation is not rooted firmly in South African library and archive sectors, information about preservation developments and activities can be hard to locate, and many information professionals are frustrated by the lack of a consistent information flow. Professional organizations, both national and international, take the lead in disseminating information, but not all are as involved or successful as they could be. Other concerns, including language issues, fluctuating currency rates, and limited professional networking opportunities, restrict South African professionals' exposure to a wider range of preservation information.

The future of preservation in South Africa lies not necessarily with more outside international assistance but within all levels of the local library and archive sector. The South African preservation community needs to continue to develop local expertise and find ways to more successfully disseminate its activities to the wider information worker population. The SAPCON Web site currently in development would be a good place to advertise ongoing and planned projects and to promote local skills. Another option is to establish a preservation column in a regularly published local journal like SAJLIS or S.A. Archives Journal or even develop an occasional preservation newsletter for a specifically South African or SADC audience. In addition, current and future education and training efforts of the institutional preservation community must be met with the managerial support that would allow these knowledgeable professionals the time and resources to further develop networking skills at home and abroad. Continued international backing is vital in areas such as research and digitization, but the emphasis should shift to self-reliance and internal capacity building as more and more South African professionals develop preservation expertise. Moreover, general information workers need to insist on more information about preservation in both their professional training programs and places of work. As the demand for increased and sustained preservation information grows within the library and archive community, South African working professionals and educators must develop workable solutions to meet the changing needs of the profession and its constituents.

\section{Works Cited}

Adcock, E. P., ed. 1998. Principles for the care and handling of library material. IFLA Professional Reports 8. Paris: IFLA PAC; Washington, D.C.: CLIR. Accessed Aug. 8, 2003, www.ifla.org/VI/4/news/pchlm.pdf.

Bergdahl, B. 1993. Pan-African conference on the preservation and conservation of library and archives material, Nairobi, 20-25 June 1993. IFLA Journal 19, no. 4: 464-66.

Buchanan, S. 1988. Disaster planning, preparedness and recovery for libraries and archives, RAMP publication with guidelines. PGI-88/WS/6. Paris: UNESCO.

Clements, D. W. G. 1987. Preservation and conservation of library and archival documents: A UNESCO/IFLA/ICA enquiry into the current state of the world's patrimony. PGI87/WS/15 rev. Paris: UNESCO. Accessed July 10, 2002, www.unesco.org/webworld/ramp/html/r8715e/r8715e00.htm.

Cloonan, M. V. 1994. Global perspectives on preservation education. IFLA Publications 69. Munich: K. G. Saur. 
Coates, P. 1995. Preservation in South Africa. In Proceeding of the Pan-African conference on the preservation and conservation of library materials, Nairobi, Kenya, June 21-25, 1993. eds. J. M. Arnoult, V. Kremp, and M. Musembi. IFLA Professional Reports 43. The Hague, Netherlands: IFLA. - comp. 2001. JICPA survey of preservation resources in Africa 1999. Cape Town: JICPA.

Digital Imaging Project of South Africa (DISA). 2001. DISA: Digital imaging project of South Africa. Accessed June 28, 2002, http://disa.nu.ac.za/index.html.

Dosa, M., and Katzer, J. 1991. Electronic networking in support of south-to-south co-operation. Journal of Education for Library and Information Science 32, no. 1/2: 84-96.

Hart, A., et al. 2001. Preservation for rural libraries in developing regions: Training librarians for volunteer service. International Preservation News 25 (August): 10-11. Accessed Aug. 8, 2003, http://ifla.queenslibrary.org/VI/4/ news/ipnn25.pdf.

International Council on Archives (ICA). 2002. The mission of ICA. Accessed Aug. 8, 2003, www.ica.org/static.php? ptextid $=$ mission\&plangue $=$ eng .

International Federation of Library Associations and Institutions (IFLA). 1993. Report of the IFLA mission to South Africa, June 1993. The Hague, Netherlands: IFLA.

. 2001. Core programme for preservation and conservation (PAC). Accessed Aug. 8, 2003, www.ifla.org/VI/4/pac.htm.

- 2002a. IFLA Africa section strategic plan, 2002-2003.

Accessed Aug. 8, 2003, www.ifla.org/VII/s25/annual/ sp25.htm.

— 2002b. Minutes of the IFLA/Africa regional section standing committee meeting, Feb. 5-7, 2002. Dakar, Senegal. The Hague: IFLA.

Joint IFLA/ICA Committee for Preservation in Africa (JICPA). 2001. Joint IFLA/ICA Committee for Preservation in Africa. Accessed Aug. 8, 2003, http://epa-prema.net/jicpa/.

Kathpalia, Y. P. 1984. A model curriculum for the training of specialists in document preservation and restoration: A RAMP study with guidelines. PGI-84/WS/2. Paris: UNESCO.

Lancaster, F. W. 1991. What has UNESCO achieved in education and training for the information professions? Journal of Education for Library and Information Science 32, no. 1/2: 69-76.

Library and Information Association of South Africa (LIASA). 2002. Library and Information Association of South Africa. Accessed Aug. 8, 2003, http://home.imaginet.co.za/liasa.

Mazikana, P. C. 1995. An evaluation of preservation and conservation programmes and facilities in Africa. In Proceeding of the Pan-African conference on the preservation and conservation of library and archival materials, Nairobi, Kenya, June 21-25, 1993. eds. J. M. Arnoult, V. Kremp, and M.
Musembi. IFLA Professional Reports 43. The Hague, Netherlands: IFLA.

Murray, K. 2002. Preservation education for South African library and archive professionals and students. Master's thesis. University of Cape Town.

Pascoe, M. W. 1988. Impact of environmental pollution on the preservation of archives and records: A RAMP study. PGI88/WS/18. Paris: UNESCO. Accessed Aug. 8, 2003, www. unesco.org/webworld/ramp/html/r8818e/r8818e00.htm.

Roberts, M. T., and D. Etherington. 1982. Bookbinding and the conservation of books: A dictionary of descriptive terminology. Washington, D.C.: Library of Congress. Accessed Aug. 8, 2003, http://palimpsest.stanford.edu/don/don.html.

Smith, M. 1992. The dissemination of preservation information. In Managing the preservation of serial literature: An international symposium. Conference held at the Library of Congress, Washington, D.C., May 22-24, 1989. ed. M. Smith. IFLA Publications 57. Munich: K. G. Saur.

South African Museums Association (SAMA). 2001. South African museums association. Accessed Aug. 8, 2003, http://sama.museums.org.za/index.html.

South African Preservation and Paper Conservation Group (SAPCON). 2001. Constitution. Duplicated.

South African Qualifications Authority Standards Generating Body for Archives and Records Management (SAQA SGBARM). 2001. Main purpose of ARM. Accessed Aug. 7, 2003, www.archives.org.za/SGBWeb site/purposes.html.

South African Society of Archivists (SASA). 2001. South African Society of Archivists. Accessed Aug. 7, 2003, www.archives. org.za/home.html.

United Nations Education, Scientific, and Cultural Organization. 1994. UNESCO General Information Programme: Memory of the World Programme: Report from the International Advisory Committee's first meeting, Pultusk, Poland, Sept. 1993. IFLA Journal 20, no. 3: 350-56.

2000. UNESCO archives portal: List of RAMP studies. Accessed July 10, 2003, www.unesco.org/webworld/portal_ archives/ramp_studies_list.html.

- 2001. Memory of the world programme: Preserving documentary heritage. Accessed May 4, 2002, www.unesco.org/ webworld/mdm/en/index_mdm.html.

Varlamoff, M. T., and V. Kremp. 2000. Annual report 1999 of the IFLA PAC core programme. IFLA Journal. 26, no. 3: 223-26.

Wood Lee, M. 1988. Prevention and treatment of mold in library collections with an emphasis on tropical climates: A RAMP study. PGI-88/WS/9. Paris: UNESCO. Accessed July 10, 2002, www.unesco.org/webworld/ramp/html/r8809e/ r8809e00.htm. 